\title{
Great discoveries of milk for a healthy diet and a healthy life
}

\author{
Donald L. Palmquist ${ }^{1}$
}

${ }^{1}$ Department of Animal Sciences - The Ohio State University - Wooster.

ABSTRACT - Extensive research in recent years has shown that consumption of milk and dairy products, promotes cardiovascular health, reduces symptoms of the metabolic syndrome in obese individuals, promotes weight loss while maintaining body muscle mass and reduces incidence of some cancers. Detailed analysis of prospective studies in large Western populations over long periods of time demonstrates that higher consumption of dairy products provides an overall survival advantage.

Key Words: cancer, cardiovascular health, diabetes, healthy diets, milk

\section{Grandes descobertas do leite para uma dieta e vida saudáveis}

\begin{abstract}
RESUMO - Nos últimos anos, inúmeras pesquisas têm mostrado que o consumo de leite e produtos lácteos melhora a saúde cardiovascular, reduz os sintomas da síndrome metabólica em indivíduos obesos, promove a perda de peso, enquanto mantém a massa muscular do corpo, e reduz a incidência de alguns tipos de câncer. A análise detalhada de estudos prospectivos em grandes populações ocidentais durante longos períodos de tempo demonstra que maior consumo de produtos lácteos proporciona uma vantagem de sobrevida global.
\end{abstract}

Palavras-chave: câncer, diabetes, dietas saudáveis, leite, saúde cardiovascular

\section{Introduction}

Milk has been known as "Mother Nature's most perfect food" for decades, if not centuries. This attribution is due to it being the only food that alone is able to sustain life and growth of mammals. Despite its qualities as a food, milk has come under increasingly negative pressure by activists of many kinds: vegetarians, food faddists, animal welfare groups, and others, who often wrongly describe milk as "food for calves only".

The nutritional qualities of milk have been attributed mainly to the principle nutrient components: its content of high quality protein, calcium, Vitamin D and other minerals and vitamins. Conversely, it has long been maligned for its saturated fat content (Table 1) and intolerance to lactose by some. In recent years, research has shown that milk has many qualities that characterize it as a "functional food"; that is, its components have physiological effects on well-being of the body that go far beyond providing the basic nutrients and energy required for growth (Huth et al., 2006). The purpose of this presentation is to highlight the functional properties of milk components and to show how milk products in the diet contribute to a healthy lifestyle. Some bioactive agents of milk with implications for human health are itemized in Table 2 (Bauman et al., 2006).

\section{Probiotics}

The components of milk contribute to health both directly and indirectly. Use of milk as a probiotic is the best known indirect contribution (Clancy \& Pang, 2000; Reid, 2008; Vasiljevic \& Shah, 2008; O’Flaherty \& Klaenhammer, 2010). Milk is fermented to yogurt by many different organisms, mainly by Lactobacillus species.

Probiotic bacteria are live microorganisms that, when administered in adequate amounts become established in the large intestine and colon and confer a health benefit on the host. There is a growing interest in probiotics within the scientific community, with consumers, and in the food industry. The interactions between the gut and intestinal microbiota and between resident and transient microbiota define a new arena in physiology, an understanding of which would shed light on the "cross-talk" between humans and microbes. The different beneficial effects of specific probiotic strains may be translated into different health claims. The symbiotic relationship between ruminal

Corresponding author: palmquist.1@osu.edu 
Table 1 - Proportions (\% of total fatty acids) of major fatty acids in milk fat (Jensen, 2002)

\begin{tabular}{llc}
\hline $\begin{array}{l}\text { Fatty acid } \\
\text { carbon number }\end{array}$ & $\begin{array}{l}\text { Fatty acid } \\
\text { common name }\end{array}$ & $\begin{array}{l}\text { Average range } \\
\text { (wt\%) }\end{array}$ \\
\hline $4: 0$ & Butyric & $2-5$ \\
$6: 0$ & Caproic & $1-5$ \\
$8: 0$ & Caprylic & $1-3$ \\
$10: 0$ & Capric & $2-4$ \\
$12: 0$ & Lauric & $2-5$ \\
$14: 0$ & Myristic & $8-14$ \\
$15: 0$ & Pentadecanoic & $1-2$ \\
$16: 0$ & Palmitic & $22-35$ \\
$16: 1$ & Palmitoleic & $1-3$ \\
$17: 0$ & Margaric & $0.5-1.5$ \\
$18: 0$ & Stearic & $9-14$ \\
$18: 1^{2}$ & Oleic & $20-30$ \\
$18: 2$ & Linoleic & $1-3$ \\
$18: 3$ & Linolenic & $0.5-2$ \\
\hline
\end{tabular}

Table 2 - Some bioactive components of milk with implications for human health (Bauman et al., 2006)

\begin{tabular}{lcl}
\hline Milk protein components & Milk fat components & Other \\
\hline Whey proteins & Cancer & \\
Casein & Conjugated linoleic acid & Calcium \\
Lactoferrin & Vaccenic acid & Lactose \\
$\alpha$-Lactalbumin & Sphingolipids & Vitamins A and D \\
Peptides & Butyric acid & Oligosaccharides \\
& 13-methyltetradecanoic acid & Nucleosides \\
& Ether lipids & Probiotics \\
\hline Whey proteins & Cardiovascular Health & \\
Casein & Conjugated linoleic acid & Calcium \\
& Stearic acid & Vitamin D \\
& Omega-3 fatty acids & \\
\hline Whey proteins & Hypertension & Calcium \\
& & Potassium \\
& & \\
\hline Whey proteins & & Probiotics \\
Milk-fat globule membrane proteins & Conjugated linoleic acid & \\
& & \\
\hline Peptides & Bone Health & Calcium \\
& Conjugated linoleic acid & Phosphorus \\
& & Vitamin K \\
\hline
\end{tabular}


microorganisms and the host is well established. Now it seems that we must consider also a symbiotic relationship between humans and their gut microbes.

An international expert group of the International Life Sciences Institute (ILSI) has evaluated the published evidence of the functionality of different probiotics in four areas of human application: 1) metabolism, 2) chronic intestinal inflammatory and functional disorders, 3) infections, and 4) allergy. Based on the existing evidence, concrete examples of demonstration of benefits and gaps are listed, and guidelines and recommendations are defined that should help design the next generation of probiotic studies (Rijkers et al, 2010; see also the accompanying papers).

Probiotics alter the gut microflora and have characteristics that include being of human origin, have generally regarded as safe (GRAS) status, acid and bile stability, adherence to intestinal cells, persistence for some time in the gut, ability to produce antimicrobial substances, antagonism against pathogenic bacteria, and ability to modulate the immune response. Of course such organisms may not have all these characteristics. Probiotic activity has been associated with Lactobacilli, Bifidobacteria, Streptococcus, Enterococcus, nonpathogenic E. coli, and Saccharomyces boulardii.
Beneficial effects attributed to the consumption of probiotic products include alleviation of lactose intolerance, protection from or decreased duration of gastrointestinal infections, suppression of cancer, reduction in plasma cholesterol concentrations, and improved digestion and nutritional value of foods. Multiple mechanisms have been proposed to account for probiotic action in different clinical conditions (Figure 1). In the context of host defense against infection, probiotic mechanisms may include competitive metabolic interactions, the production of antimicrobials, and inhibition of adherence or translocation of pathogens. In the context of inflammatory bowel disease, antiinflammatory bacteria may signal through the gastrointestinal epithelium and perhaps mucosal regulatory T cells or dendritic cells. Different probiotics may be used for different gastrointestinal diseases such as diarrhea in patients with irritable bowel syndrome, ulcerative colitis, pouchitis, Crohn's disease and chemotherapy-induced diarrhea in colon and breast cancer patients.

By the nature of fermentation of yogurts and some cheeses, lactose is converted to lactic acid and other end products, resulting in low lactose content that can be tolerated by those suffering lactose intolerance. Also, lactose is removed effectively in the production of hard cheeses, the lactose being recovered in whey.

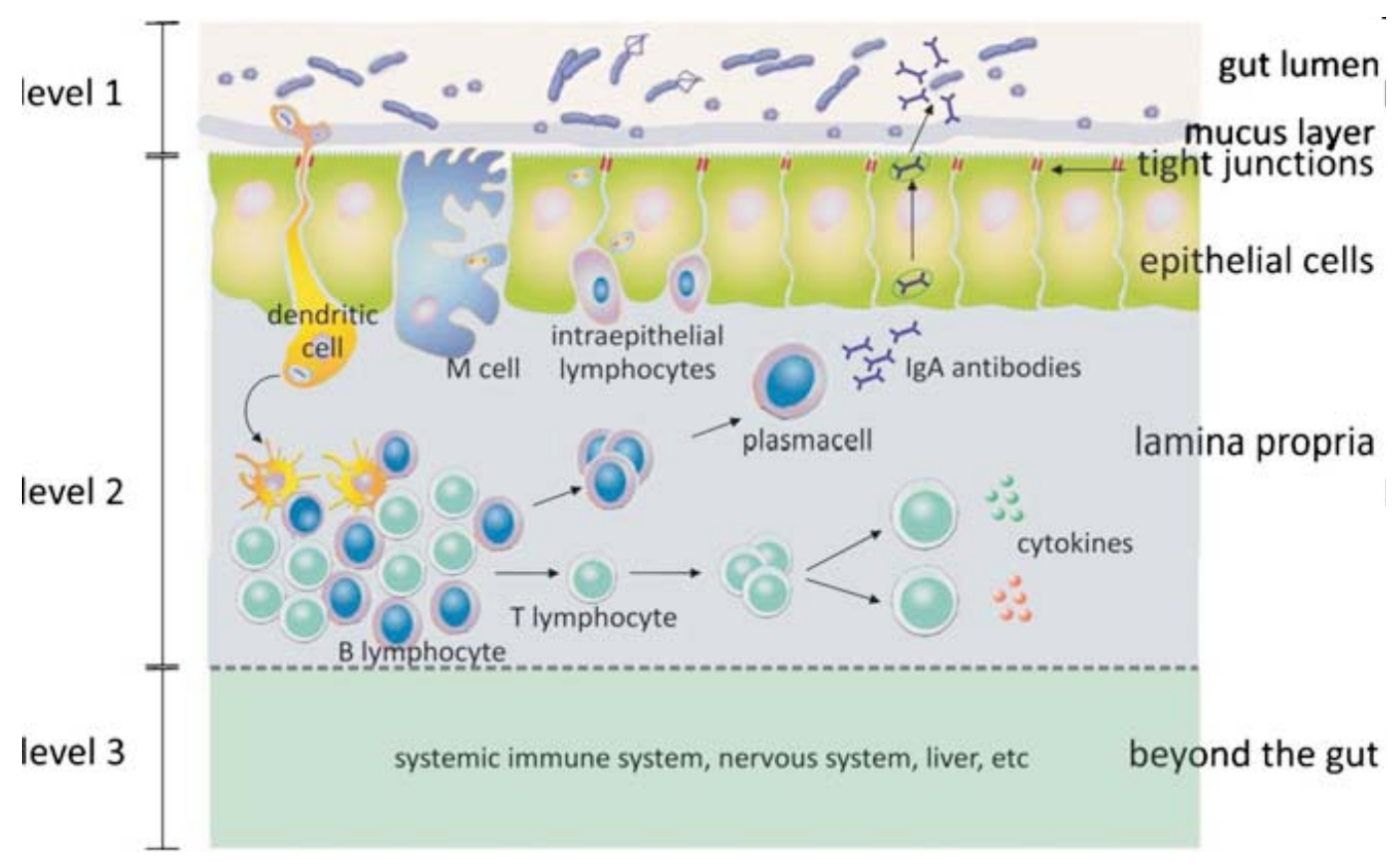

Figure 1 - The 3 levels of action of a probiotic. Probiotic bacteria can interfere with growth or survival of pathogenic microorganisms in the gut lumen (level 1). Probiotic bacteria can improve the mucosal barrier function and mucosal immune system (level 2) and, beyond the gut, have an effect on the systemic immune system as well as other cell and organ systems such as liver and brain (level 3) (Rijkers et al., 2010). 
Specific effects of individual fatty acids

Fatty acid profile of bovine milk

Ruminant milks are rather similar in gross fatty acid composition, but important differences exist, so this paper will focus on bovine milk fat. Jensen (2002) has catalogued $\sim 400$ different fatty acids in milk fat; most of these are products of ruminal microbial modification of dietary fatty acids. The fatty acids of ruminant milk have a dual origin (Palmquist, 2006a). Those of chain length $C_{4}$ to $C_{14}$ are derived from de novo synthesis in the mammary glands, whereas those of $\mathrm{C}_{18}$ and longer are derived from the diet. The fatty acid of greatest proportion, $\mathrm{C}_{16}$, arises from both sources; the relative amounts from each source can be influenced by the diet.

From the time of the publication of papers by Ancel Keys and colleagues (Keys et al., 1957) that purportedly showed saturated fatty acids from dairy foods as being highly atherogenic, dairy fats have been under attack by the medical community and others. Widely overlooked was that these papers used selected data that were grossly overinterpreted. Much early research tended to support Keys' data, due to limited understanding of lipid metabolism and faulty experimental design. Though more modern research has disproven many of the early concepts that dairy products and saturated fat contribute to cardiovascular diseases (CVD), the medical community and the public press continue to attack dairy foods as components of unhealthy diets. Such misinformation also has been incorporated into public policy on the value of dairy foods in healthy diets (see www.dietaryguidelines.gov). However, the topic of the current discussion is to focus on research that shows the positive effects of milk in diets.

\section{Saturated fatty acids}

Milk is often described as having " $70 \%$ saturated fatty acids". This is inaccurate and exaggerated Such accounting includes the short chain ( $<12 \mathrm{C}$ in the fatty acid chain) fatty acids that are largely oxidized in the liver upon absorption and have never been implicated in CVD. These constitute up to $15 \%$ of milk fatty acids. Further, stearic acid (18:0) is 9 to $15 \%$ of milk fatty acids, and has been shown clearly to not be atherogenic. Those that have been shown to have atherogenic properties are lauric (12:0), myristic (14:0) and palmitic (16:0) acids (Mensink et al., 2003). In most milk fats, the sum of these is about $45 \%$ of the total milk fatty acids. In healthy, well-balanced diets, atherogenicity even of these may be questioned. Lauric acid does increase plasma cholesterol concentrations, but most of the increase is in high density lipoproteins (HDL), with consequent increase in HDL/LDL ratio (Figures 2A and 2B), which is considered to be a positive marker for cardiovascular health (Fernandez \& Webb, 2008). The atherogenicity of palmitic acid has long been uncertain, perhaps because when included in diets that contain adequate quantities of unsaturated fatty acids, no negative effects of 16:0 are evident (Clandinin, 2000). A recent meta-analysis of prospective epidemiologic studies (Siri-Torino et al., 2010) showed that there is no significant evidence for concluding that dietary saturated fat is associated with an increased risk of CHD or CVD (Figure 3). Parodi (2009) has documented in depth that milk fat is not a negative for heart health.

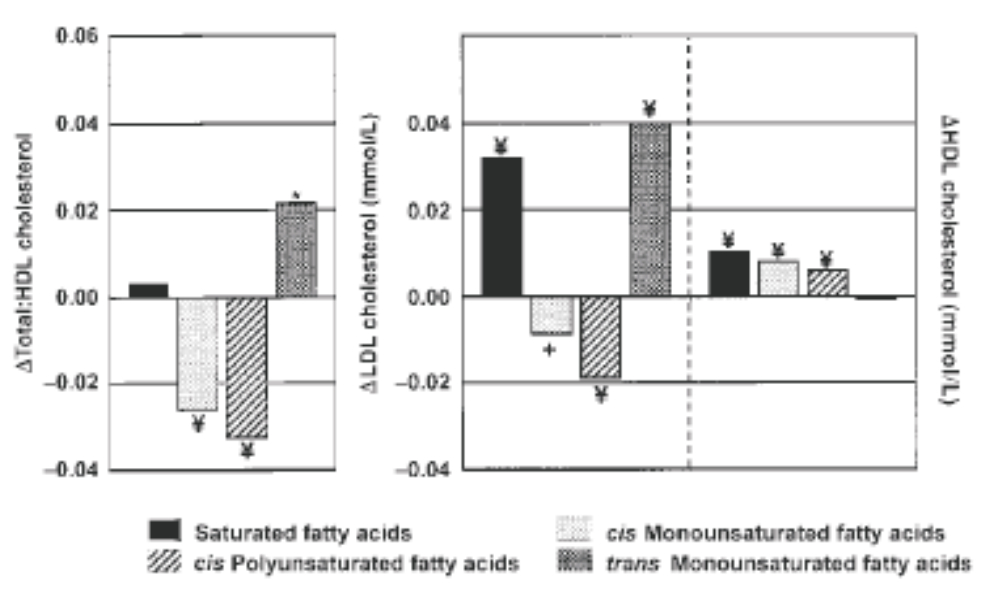

Figure 2A - Predicted changes in the ratio of serum total to HDL cholesterol and in LDL- and HDL-cholesterol concentrations (mmole/l) when carbohydrates constituting 1\% of energy are replaced isoenergetically with saturated, cis monounsaturated, cis polyunsaturated, or trans monounsaturated fatty acids.

* $\mathrm{P}<0.05 ;+\mathrm{P}<0.01 ; ¥ \mathrm{P}<0.001$; Mensink et al. (2003). 

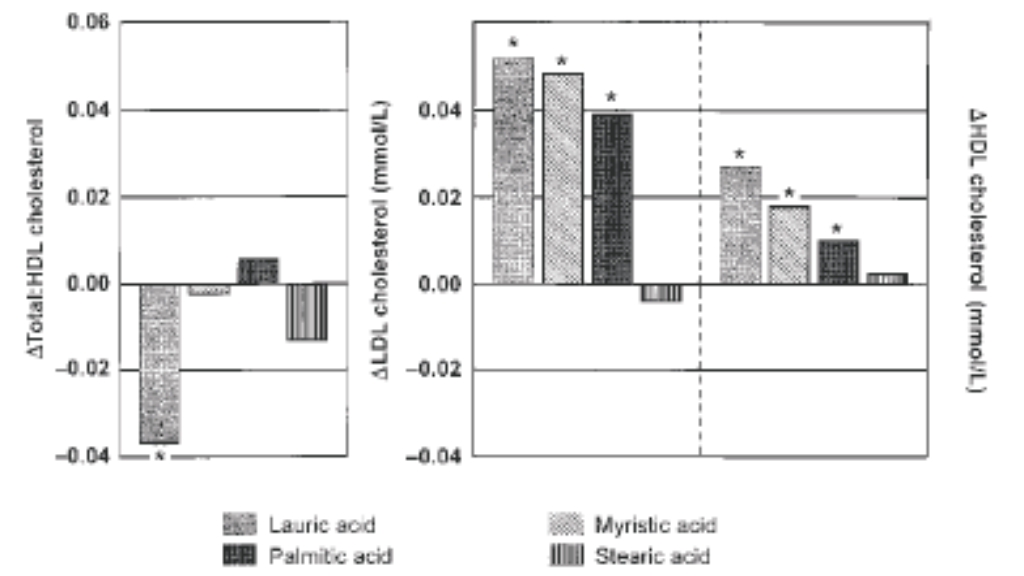

Figure 2B - Predicted changes in the ratio of serum total to HDL cholesterol and in LDL- and HDL-cholesterol concentrations (mmole/ l) when carbohydrates constituting $1 \%$ of energy are replaced isoenergetically with lauric acid (12:0), myristic acid (14:0), palmitic acid (16:0), or stearic acid (18:0).

$* \mathrm{P}<0.001$; Mensink et al. (2003).

Risk Ratio Stucty or Subgroup IV, Random, 95\% Cl Year Coronary Heart Disease

Shekelle et al(17)

McGee et al $(9)^{1}$

Kushi et al(13)

Posner et al(16)

Goldbourt et al(35) ${ }^{1}$

Fehily et al(28)

Ascherio et al(4) ${ }^{1}$

Esrey et al(6)

Mann et al(32)

Pietinen et al(15)

Boniface et al(5) ${ }^{1}$

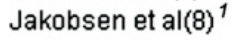

Oh et al(33)

Tucker et al(18) ${ }^{1}$

$\mathrm{Xu}$ et al(10)

Leosdottir et al(14)

Subtotal (95\% Cl)

Heterogeneity: $\mathrm{Tau}^{2}=0.02 ; \mathrm{Chi}^{2}=25.54, \mathrm{df}=15(\mathrm{P}=0.04) ; \mathrm{I}^{2}=41 \%$

Test for overall effect: $Z=1.22(P=0.22)$

\section{Stroke}

McGee et al( $(9)^{1}$

Goldbourt et al(35) ${ }^{1}$

Gillman et al(11)

Iso et al(31)

$\mathrm{He}$ et al(29) ${ }^{1}$

Iso et al(30)

Sauvaget et al(34)

Leosdottir et al(14)

Subtotal (95\% CI)

$1.11[0.91,1.36] 1981$

$0.86[0.67,1.12] 1984$

$1.33[0.95,1.87] 1985$

$0.92[0.68,1.24] 1991$

$0.86[0.56,1.35] 1993$

$1.57[0.56,4.42] 1994$

$1.11[0.87,1.42] 1996$

$0.97[0.80,1.18] 1996$

$2.77[1.25,6.13] 1997$

$0.93[0.60,1.44] 199 ?$

$1.37[1.17,1.60] 2002$

$1.03[0.66,1.60] 2004$

$0.97[0.74,1.27] 2005$

$1.22[0.31,4.77] 2005$

$1.91[0.31,11.84] 2006$

$0.95[0.74,1.21] 2007$

$1.07[0.96,1.19]$

Heterogeneity: $\mathrm{Tau}^{2}=0.08 ; \mathrm{Chi}^{2}=18.03, \mathrm{df}=7(P=0.01) ; \mathrm{I}^{2}=61 \%$

Test for overall effect: $Z=1.58(P=0.11)$

\section{Total $(95 \% \mathrm{Cl})$}

$1.00[0.89,1.11]$

Heterogeneity: $\mathrm{Tau}^{2}=0.03 ; \mathrm{Chi}^{2}=52.63, \mathrm{df}=23(\mathrm{P}=0.0004) ; \mathrm{I}^{2}=56 \%$

Test for overall effect: $Z=0.06(P=0.95)$
Risk Ratio

N, Random, $95 \% \mathrm{Cl}$

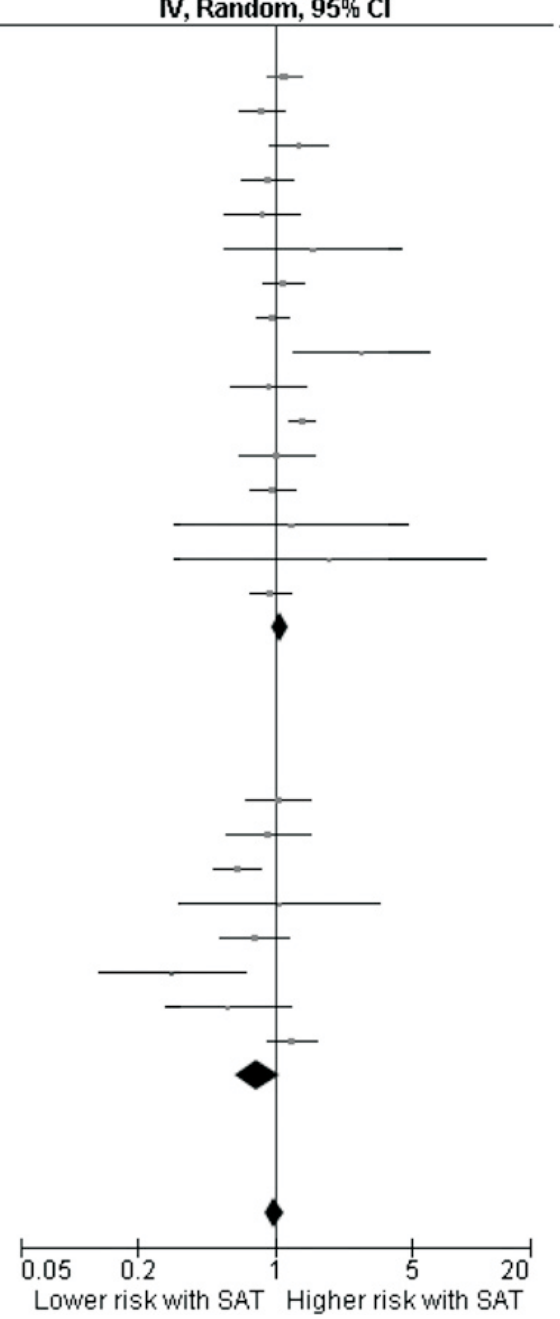

Figure 3 - Risk ratios and 95\% CIs for fully adjusted random-effects models examining associations between saturated fat intake in relation to coronary heart disease and stroke (Siri-Torino et al., 2010). 
The nature of the LDL particles might even be more favorable from a cardiovascular perspective in subjects with higher levels of typical dairy fatty acids; most notably, dairy fats raise solely the larger and less atherogenic subpopulation of LDL particles (Sjõgren et al., 2004). Such findings are consistent with the conclusion that simple measures of total LDL-cholesterol (LDL-C) does not predict overall cardiovascular risk as well as detailed analyses of LDL subpopulations. Higher plasma concentrations of LDLC, carried by apolipoprotein B (ApoB), and specifically the smaller, dense LDL particles, higher plasma triacylglycerol concentrations and low plasma HDL-cholesterol (HDL-C) are associated with increased risk of heart disease.

Promoting HDL-C is becoming an important target for lowering the risk of CVD in the population. The ability of saturated fat to raise LDL-C may depend on a polyunsaturated fat content below a threshold level ( $<5 \%$ of diet energy intake), a condition not usually occurring in human diets. Further, dietary carbohydrate modulates the effect of saturated fat on lipid and lipoprotein profiles by increasing plasma triglyceride concentrations, reducing HDL-C and increasing concentrations of small, dense LDL-the subclass of LDL that is considered to be more atherogenic - by increasing hepatic triglycerides. Replacing saturated fat with carbohydrate results in a reduction in both total cholesterol and HDL-C, with no effect on the ratio of total cholesterol to HDL-C. The role of lipids in cardiovascular health has been addressed widely in recent publications (Lamarche, 2008; Lock et al., 2008, 2009).

\section{Trans fatty acids}

Whereas fatty acids from hydrogenated vegetable oils (HVO) are related clearly to increases in the LDL cholesterol/ HDL ratio, no such link has been demonstrated for the trans fatty acids of ruminant fats (Figures 4A and 4B; Willett et al., 1993). This is explained by the differences in distribution of the trans monoenes between HVO and ruminant fat. In HVO the trans monoenes show a Gaussian distribution of

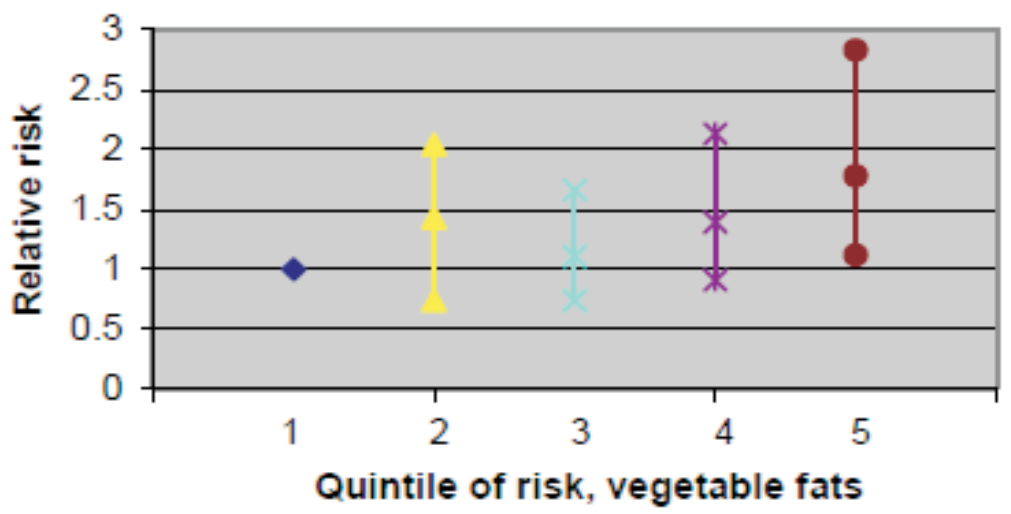

Figure 4A - Relative risk (median and range) of CHD in relation to quintiles of energy-adjusted trans fatty acid intake from vegetable fats. Quintile 5 vs. 1, $\mathrm{P}<0.01$.

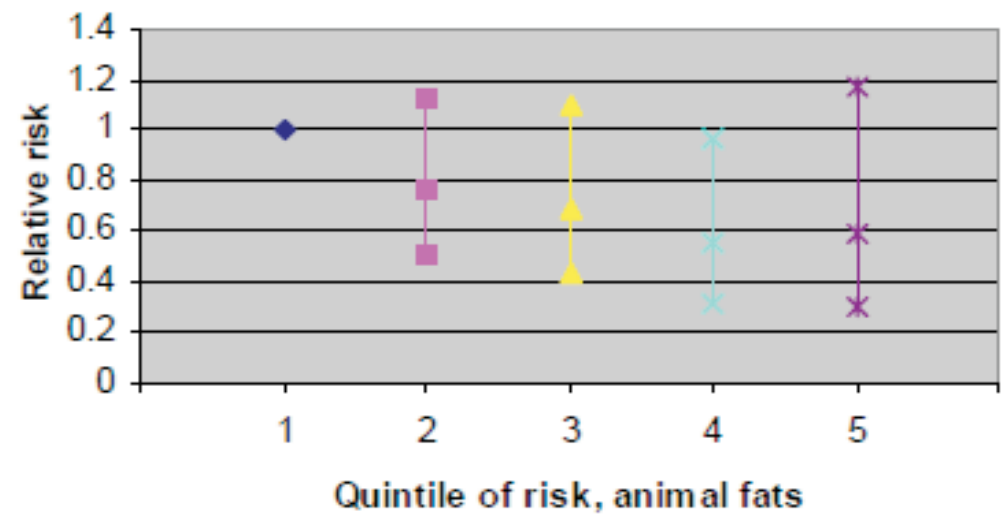

Figure 4B - Relative risk (median and range) of CHD in relation to quintiles of energy-adjusted trans fatty acid intake from animal fats, $\mathrm{P}=0.23$; Willett et al. (1993). 
the double bond around the $\Delta-9$ double bond, whereas the predominant trans double bond in ruminant fat is $\Delta-11$.

\section{Conjugated linoleic acid}

Conjugated linoleic acid (CLA) is a collective term for isomers of linoleic acid with conjugated double bonds in several positions and conformations that arise from isomerization of dietary fatty acids during biohydrogenation (BH) by ruminal microorganisms, and by subsequent metabolism of certain of the isomers in the animal (Griinari et al., 2000). Rumenic acid is particularly rich in ruminant meat and milk from grazing ruminants or those fed certain high fat diets. CLA has received considerable interest during the past decade, because it has been shown to promote various beneficial health-related effects in animals, including anti-carcinogenic and anti-atherogenic effects and effects on body composition and fat metabolism (Benjamin \& Spener, 2009). The predominant CLA isomer in ruminant fats is rumenic acid (RA); the majority-up to 95\% — of milk CLA is derived by de novo synthesis in the mammary glands (Griinari et al., 2000) by $\Delta-9$ desaturation of vaccenic acid (trans-11 18:1, arising from ruminal $\mathrm{BH}$; Palmquist et al., 2005).

Whereas RA has been shown to induce numerous physiological responses in experimental animals, clinical evidence for health benefits in humans are very few. Mechanisms of action are apparently primarily at the cellular level, inducing changes in gene expression through binding to various gene response elements. Extensive research has been carried out with synthetic mixtures of CLA, most of which contain equal amounts of RA and the trans-10, cis-12 18:2 isomer. The latter induces much different cell and physiological responses. Best characterized is its effect on lipid metabolism, including strong inhibition of fatty acid synthesis. Thus, trans-10, cis-12 18:2 has been implicated as a cause of milk fat depression in cows (Bauman \& Griinari, 2003), and has been investigated extensively as a potential weight loss agent for humans (Whigham et al., 2007). Differences between RA and trans-10, cis-12 18:2 have been shown also in human studies when the two isomers were used separately (Ip et al., 1999; Ramakers et al., 2005; Kelley et al., 2007; Goedecke et al., 2009; Herrmann et al., 2009). For an extensive bibliography on CLA, see http://fri.wisc.edu/clarefs.htm.

There is no dietary human requirement as such for CLA. Though most animal model research suggests that intakes needed to induce significant health responses may be as much as 1 gram/day, estimated daily intakes range from $\sim 100 \mathrm{mg} /$ day in United States studies to $300-400 \mathrm{mg} /$ day in Europe. These differences are attributed to greater intake of foods from ruminant origin in Europe, perhaps mainly cheese. Availability of CLA in the diet from ruminants on grass-based systems was reviewed by Van Wijlen \& Colombani (2010). Because milk fat contains $\sim 3$ times as much vaccenic acid as CLA, it is significant that humans, as well as cows, are capable of desaturating vaccenic acid to synthesize RA endogenously. About 20\% of dietary vaccenic acid was converted to RA in a Finnish human study (Turpeinen et al., 2002). Parodi (2006) used this value to conclude that the amount of CLA available to human tissues is 1.4 times that consumed in ruminant products.

\section{Unsaturated fatty acids}

Monounsaturated fatty acids are primarily cis $916: 1 n-7$ and cis-9 18:1n-9 (oleic acid). Oleic acid (cis-9 18:1), considered universally to be a desirable component of dietary fat, is the second most abundant fatty acid in milk fat. Its content is variable, influenced by the dietary fat content, and the extents of ruminal biohydrogenation and mammary $\Delta-9$ desaturase activity. With higher dietary fat content, significant amounts of $18: 1$ appear as the $\Delta-10$ and $\Delta-11$ isomers. The $\Delta-11$ isomer (vaccenic acid) is less than $2 \%$ of total fatty acids with normal ruminal metabolism. When highly unsaturated diets are fed, one-half or more of 18:1 in milk fat may be trans isomers and one-half of this as $\Delta-10$ when milk fat depression occurs (Palmquist \& Griinari, 2006b).

The "beneficial” polyunsaturated fatty acid content of ruminant milk fat is low; linoleic acid (18:2n-6) ranges from 2 to $4 \%$, and linolenic acid (18:3n-3) is usually $<1 \%$. Though the content of these in the cow's diet is high, both are efficiently biohydrogenated in the rumen, with the main end product being 18:0, with lesser amount of vaccenic acid. Due to pressure from the medical industry over the past 50 years, intake of n-6 ( $\omega-6)$ fatty acids such as linoleic has increased greatly, mainly from corn and soybean oil. It is believed now by many that high intake of n-6 fatty acids has caused severe imbalance of n-6/n-3 ratio, causing certain human diseases, such as the metabolic syndrome, to be increased. So the supply of n6 fatty acids in milk is not an issue; however, intake of the desirable n-3 fatty acid, linolenic, remains low. The content of linolenic acid in milk fat can be increased by selected feeding practices (Palmquist, 2009), most directly by grazing dairy cattle on high-quality pastures (Dewhurst, 2006). There has been considerable research effort to increase the very long chain "fish oil” fatty acids in milk fat by feeding oils from fish or certain algae. This can be accomplished to a limited extent, but feeding these oils at $>1 \%$ of feed dry matter causes decreased feed intake and 
greatly changes the distribution of $\mathrm{BH}$ products in ruminal content (Shingfield et al., 2003).

Other fatty acids of interest

Though CLA and n-3 fatty acids have received greatest attention, certain other milk fatty acids have been shown to have biological functions. Of these, branched chain fatty acids are known to bind to nuclear receptors, with subsequent modification of gene expression. These include 13-methyl tetradecanoic acid (iso-15:0), and phytanic acid (3, 7, 11, 15-tetra methyl-16:0), and the derivative of the latter, pristanic acid. Phytanic acid has been shown to increase insulin-independent glucose uptake by cells and to decrease liver triglyceride accumulation in some mouse models (Heim et al., 2002; Hellgren, 2010). Palmitoleic acid, the $\Delta-9$ desaturation product of palmitic acid, has been demonstrated to effect a hormone-like (lipokine) activation of glucose uptake in muscle cells (Cao et al., 2008; Olefsky, 2008).

\section{Milk proteins}

There is a considerable body of research on milk proteins, much with respect to cancer (Micke et al., 2002; Parodi, 2007). More focus concerns whey, especially the effects of the high-sulfur proteins it contains.

Whey

Whey is a byproduct of cheese-making; it contains five major proteins, $\alpha$-lactoglobulin, $\beta$-lactalbumin, glycomacropeptide proteose peptone 3 , immunoglobulins, and serum albumin, which together make up $85 \%$ of whey protein. There are hundreds of minor whey proteins and peptides, many of which have multiple nutraceutic activities (Figure 5). Whey products are among the most intensively-studied of milk components for nutriceutic activity (Smithers, 2008). Whey protein is a rich source of cysteine that promotes high glutathione concentrations in blood plasma. This antioxidant peptide is among the most powerful of cellular protective mechanisms and has strong anticancer properties (Bounous, 2000; Micke et al., 2002). Whey proteins promote loss of adipose tissue while maintaining lean body mass (Zemel et al., 2004ab, 2005; Paul, 2009), and increasing lean body mass during weight training. Adding whey or skimmed milk powder to fortified blended food supplements for malnourished infants and young children or people living with HIV or AIDS improves the protein quality of supplements, allowing a reduction in total amount of protein, which could have potential metabolic advantages. Whey products improve weight gain, linear growth, and recovery from malnutrition. Bioactive factors in whey may have beneficial effects on the immune system and muscle synthesis. Milk proteins improve flavor, an important factor for acceptability of food supplements in vulnerable groups (Hoppe et al., 2006, 2008).

Oral ingestion of bovine lactoferrin, a minor protein of whey stimulates the immune system of the gut, and enhances and reconstitutes the peripheral immune system. Ingestion of lactoferrin exerts anti-cancer activity, attenuates inflammatory disease and exerts anti-microbial activity (Krissansen, 2007).

A number of human studies have associated milk protein-derived peptides with statistically significant

\section{Whey proteins}

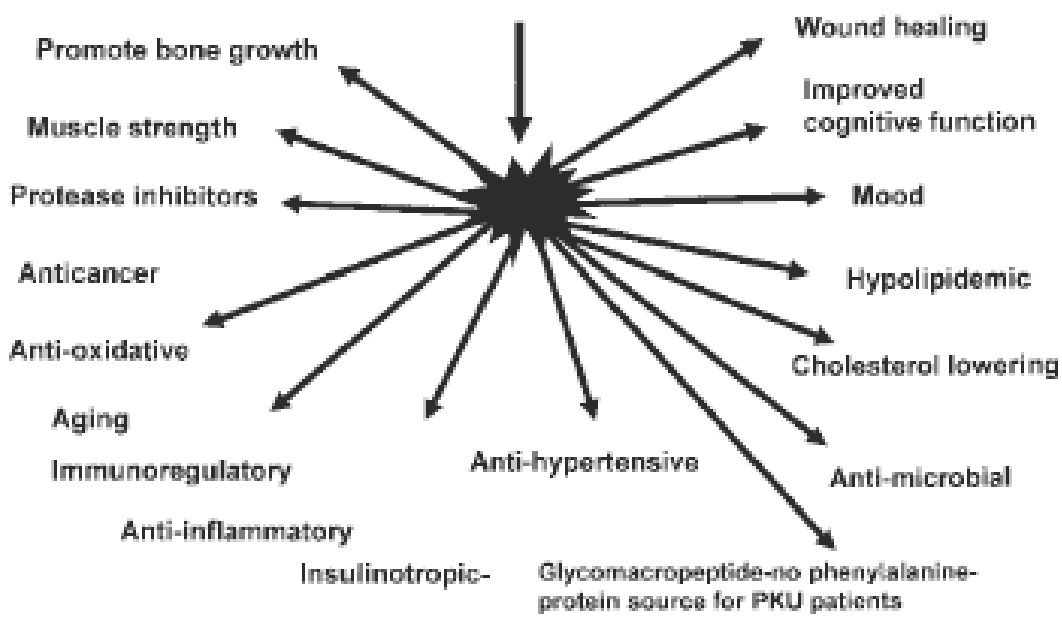

Figure 5 - Whey proteins exhibit a diverse array of functional properties that affect different biological processes and organ systems (Krissansen, 2007). 
hypotensive effects (i.e., lower systolic and diastolic pressures). Milk proteins, both caseins and whey proteins, are a rich source of ACE inhibitory peptides. Several studies in spontaneously hypertensive rats show that these casokinins and lactokinins can significantly reduce blood pressure (FitzGerald, et al., 2004; Kris-Etherton et al., 2009). Further, intestinal digestion of caseins in particular produces a myriad of bioactive peptides which may be absorbed and exert their activity in a myriad of ways, including antithrombotic, hypotensive, opiod, immunomodulation and antimicrobial activities (Silva and Malcata, 2005; Phelan et al., 2009).

Milk and dairy products-health implications

Of all the recent reports on milk consumption and health, those concerning overall healthiness and survival are perhaps of greatest interest. A recent summary (German et al., 2009) generated from a conference organized and facilitated by the International Dairy Federation's Standing Committee on Nutrition and Health provided an overview and reappraisal of the available scientific evidence examining the impact of dairy foods on CVD risk. They concluded that "though dairy products contribute to the saturated fatty acid (content) of the diet, a systematic review of prospective cohort studies, and the disparities among them, indicated that there is no clear evidence that dairy food consumption is consistently associated with a higher risk of CVD”. Studies that confirm or expand on these conclusions include: consumption of dairy products decrease blood pressure (Engberink et al., 2009; Kris-Etherton, et al., 2009); decrease blood pressure in white but not black populations (Alonso et al., 2009a); but no reduction in young, normotensive adults (Alonso et al., 2009b); and milk or milk fat intake may be inversely related to the risk of a first event of stroke (Warensjõ et al., 2009), that is influenced by elevated blood pressure, among other factors.

Associations between dairy intake and incidence of insulin resistance syndrome (the metabolic syndrome) were evaluated in a population of 3157 adults over a ten year period (Figure 6; Pereira et al., 2002). Inverse associations were observed between frequency of dairy intake and the development of obesity, abnormal glucose homeostasis, elevated blood pressure, and dyslipidemia in young overweight black and white men and women. The 10 -year incidence of the insulin resistant syndrome was lower by more than two thirds among overweight individuals in the highest category of dairy consumption ( $\geq 5$ servings/day) compared with those in the lowest category $(<1.5 / \mathrm{d})$.

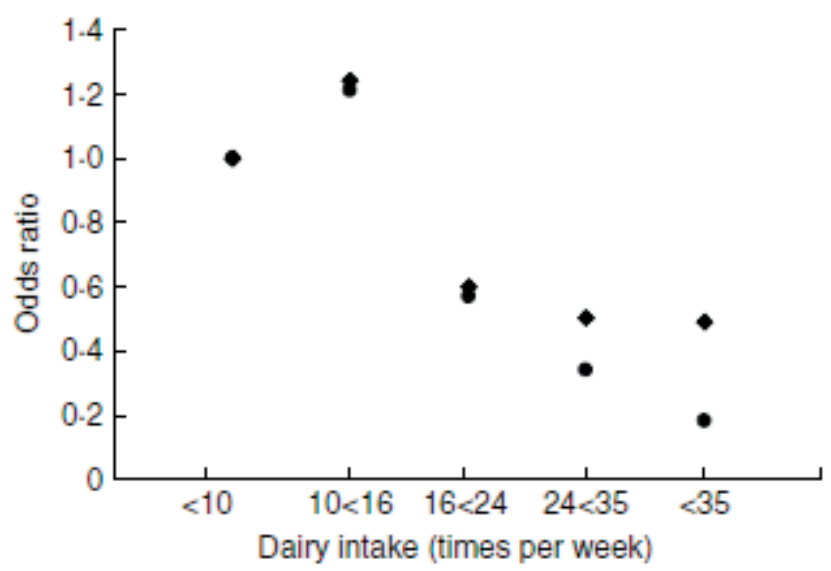

Figure 6 - Ten-year cumulative incidence of insulin resistance syndrome components by categories of total dairy intake with stratification by baseline overweight status (Pereira et al., 2002).

The association between dairy intake and insulin resistant syndrome was not observed in individuals who were not overweight $\left(\mathrm{BMI}<25 \mathrm{~kg} / \mathrm{m}^{2}\right)$ at baseline of the 10-year study, perhaps because normal weight individuals were protected from insulin resistance and obesity by other lifestyle or genetic factors. Thus, dietary patterns characterized by increased dairy consumption may protect overweight individuals from the development of obesity and the insulin resistant syndrome, key risk factors for type-2 diabetes and cardiovascular disease. These results are consistent with those of Warensjõ et al. (2004), who reported a negative association between milk fat intake and plasma markers of the metabolic syndrome. Pfeuffer \& Schrezenmeir (2006) concluded that milk in the diet has multiple positive effects on general health and well-being.

In a 16-year prospective study of 1550 Australians, overall intake of dairy products was not associated with mortality (Bonthuis et al., 2010). Ness et al. (2001) reported the relative risk of higher milk consumption (<90, 190-750, or $>750 \mathrm{ml} /$ day) for cardiovascular and total deaths of 5765 working men in the West of Scotland over a period of 25 years; relative risk for all deaths or those attributable to CVD and CHD (cardiovascular-heart disease) was decreased by increasing milk consumption, whereas deaths attributable to cancer were reduced equally for moderate or high milk consumption (Figure 7).

In a detailed evaluation, with meta-analyses, of published evidence on milk and dairy consumption and the incidence of vascular diseases and diabetes, Elwood et al. (2008) summarized the evidence on milk and dairy consumption and cancer reported by the World Cancer Research Fund, then considered the relevance of milk and 


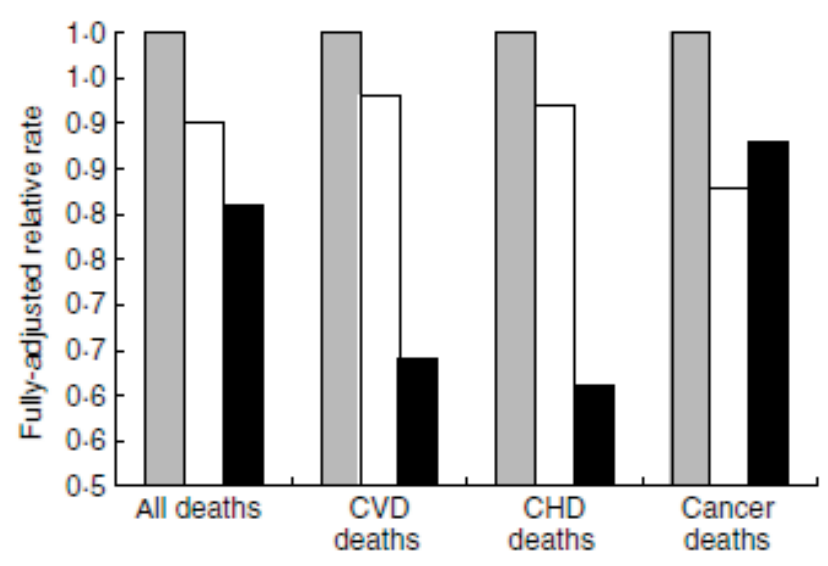

Figure 7 - Relative mortality rate (25 years) among 5765 men according to level of milk consumption: $\square$, very low; ๑, moderate; $\mathbf{m}$, high (from Ness et al., 2001). dairy consumption to survival in the UK, a typical Western community. Finally, published evidence on relationships with whole milk and fat-reduced milks was examined. From meta-analysis of 15 studies the relative risk of stroke or heart disease, or both, in subjects with high milk or dairy consumption was 0.84 (95\% CI 0.76, 0.93) and 0.79 (0.75, 0.82 ) respectively, relative to the risk in those with low consumption. Four studies reported incident diabetes as an outcome, and the relative risk in the subjects with the highest intake of milk or dairy foods was $0.92(0.86,0.97)$. Relative risk for numerous diseases by higher consumption of milk is shown in Figure 8.

These results, taken with an abundance of others, provide evidence of an overall survival advantage in Western communities from the consumption of milk and dairy foods, particularly with regard to vascular disease,

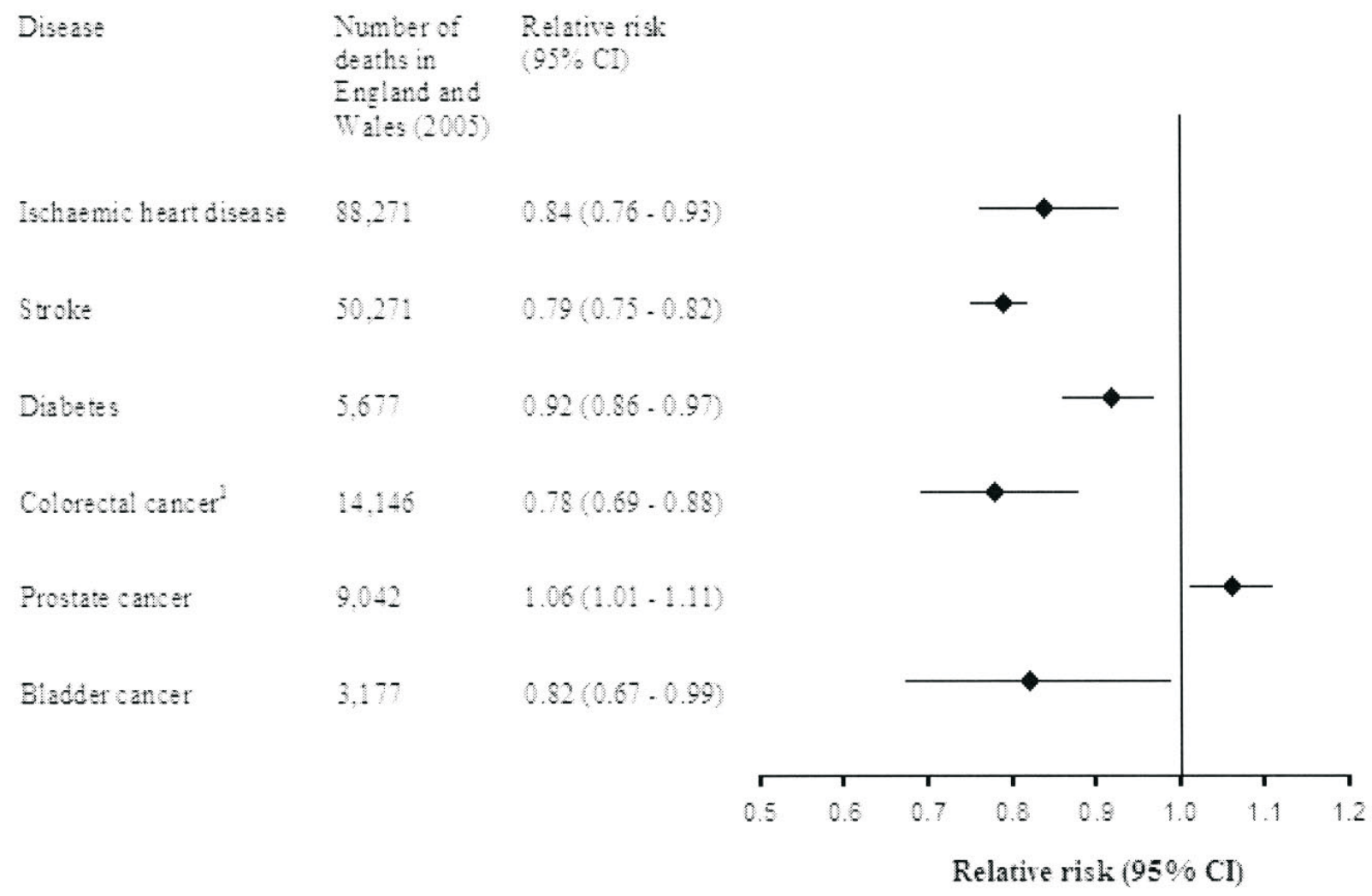

Figure 8 - Relative risk for selected diseases in England and Wales by higher milk consumption (Elwood et al., 2008). 
Type 2 diabetes and probable reduction in colon cancer. Considering that higher milk consumption may cause some increase in prostate cancer there is "fairly convincing overall evidence that milk and dairy consumption is associated with an increase in survival" (Elwood et al., 2008). Due to a focus on the small rise in blood cholesterol with milk drinking, the debate on milk has never achieved a reasonable balance in the evaluation of risks and benefits. These authors suggested that "the debate about the health risks and benefits of milk and dairy consumption in Western communities should focus on evidence of direct relevance to health and survival that would benefit greatly if it were supported by a concerted and targeted research effort to understand the underlying mechanisms.” Apart from their effects on plasma lipids and on blood pressure, very little is known about the biological mechanisms likely to be involved in the relationships of milk and dairy foods with human diseases or indeed whether milk can be modified to provide further health advantages. Clearly more work should be done. In this regard, the comments of Ward \& German (2004) and LeMay et al. (2009) are relevant: the new knowledge of the human and bovine genomes can be used to pursue key functions of the various milk components for both nutrition and survival.

Finally, as nicely summarized by Givens (2005) "In the future the role of animal nutrition in creating foods closer to the optimum composition for long-term human health is likely to become increasingly important, but production of such foods on a scale that will substantially affect national diets will require political and financial incentives and great changes in the animal production industry."

\section{Conclusions}

Fermented dairy products can enhance populations of probiotic organisms that promote improved intestinal and overall systemic health. Milk fatty acids, while increasing total plasma cholesterol, reduce the total cholesterol/HDL cholesterol ratio and concentration of atherogenic small dense lipoproteins. Several fatty acids have been characterized as having nutraceutic activities; of the $\sim 400$ milk fatty acids, only a few have been characterized for physiological effects-what others remain to be discovered? Digestion products of milk proteins reduce blood pressure and increase serum glutathione; numerous components of milk promote body weight loss while maintaining muscle mass. Consuming milk and dairy foods provides a survival advantage in Western communities, particularly with regard to reduced colon cancer, vascular disease and Type 2 diabetes.

\section{References}

ALONSO, A.; STEFFEN, L.M.; FOLSOM, A.R. Dairy intake and changes in blood pressure over 9 years: the ARIC study. European Journal of Clinical Nutrition, v.10, p.12721275, 2009a.

ALONSO, A.; ZOZAYA, C.; VÁZQUEZ, Z. et al. The effect of low-fat versus whole-fat dairy product intake on blood pressure and weight in young normotensive adults. Journal of Human Nutritrion Dietetics, v.22, p.336-342, 2009b.

BAUMAN, D.E.; GRIINARI, J.M. Nutritional regulation of milk synthesis. Annual Review of Nutrition, v.23, p.223-237, 2003.

BAUMAN, D.E.; MATHER, I.H.; WALL, R.J. et al. Review: major advances associated with the biosynthesis of milk. Journal of Dairy Science, v.89, p.1235-1243, 2006.

BENJAMIN, S.; SPENER, F. Review: Conjugated linoleic acids as functional food: an insight into their health benefits. Nutrition and Metabolism, v.6, p.36-50, 2009.

BONTHUIS, M., HUGHES, M.C.; IBIEBELE, T.I. et al. Dairy consumption and patterns of mortality of Australian adults. European Journal of Clinical Nutrition, 2010; doi:10.1038/ejcn.2010.45.

BOUNOUS, G. Whey protein concentrate (WPC) and glutathione modulation in cancer treatment. Anticancer Research, v.20, p.4785-4792, 2000.

CAO, H.K.; GERHOLD, J.R.; MAYERS, M.M. et al. Hotamisligil identification of a lipokine, a lipid hormone linking adipose tissue to systemic metabolism. Cell Press Journal, v.134, p.933-944, 2008.

CLANCY, R.L.; PANG, G. Review: probiotics - industry myth or a practical reality? Journal of the American College of Nutrition, v.26, p.691S-694S, 2007.

CLANDININ, M.T. The effect of palmitic acid on lipoprotein cholesterol levels. International Journal of Food Sciences and Nutrition, v. 51, p.S61-S71, 2000.

DEWHURST, R.J.; SHINGFIELD, K.J.; LEE, M.R.F. et al. Increasing the concentrations of beneficial polyunsaturated fatty acids in milk produced by dairy cows in high-forage systems. Animal Feed Science and Technology, v.131, p.168-206, 2006.

ENGBERINK, M.F.; HENDRIKSEN, M.A.; SCHOUTEN, E.G. et al. Inverse association between dairy intake and hypertension: the Rotterdam Study. American Journal of Clinical Nutritrion, v.89, p.1877-1883, 2009.

ELWOOD, P.C.; GIVENS, D.I.; BESWICK, A.D. et al. The survival advantage of milk and dairy consumption: an overview of evidence from cohort studies of vascular diseases, diabetes and cancer. Journal of the American College of Nutritrion, v.27, p.723S-734S, 2008.

FERNANDEZ, M.L.; WEBB, D. Review: the LDL to HDL cholesterol ratio as a valuable tool to evaluate coronary heart disease risk. Journal of the American College of Nutritrion, v.27, p.1-5, 2008.

FITZGERALD, R.J.; MURRAY, B.A.; WALSH, D.J. Hypotensive peptides from milk proteins. The Journal of Nutrition, v.134, p.980S-988S, 2004.

GERMAN, J.B.; GIBSON, R.A.; KRAUSS, R.M. et al. Review: a reappraisal of the impact of dairy foods and milk fat on cardiovascular disease risk. European Journal of Nutrition, v.48, p.191-203, 2009.

GIVENS, D.I. The role of animal nutrition in improving the nutritive value of animal-derived foods in relation to chronic disease. Proceedings of the Nutrition Society, v.64, p.395-402, 2005.

GOEDECKE, J.H.; RAE, D.E.; SMUTS, C.M. et al. Conjugated linoleic acid isomers, t10c12 and c9t11, are differentially incorporated into adipose tissue and skeletal muscle in humans, Lipids, v.44, p.983-988, 2009. 
GRIINARI, J.M.; BAUMAN, D.E.; CHILLIARD, Y. et al. Conjugated linoleic acid is synthesized endogenously in lactating dairy cows by $\Delta$-desaturase. The Journal of Nutrition, v.130, p.2285-2291, 2000.

HEIM, M.; JOHNSON, J.; BOESS, F. et al. Phytanic acid, a natural peroxisome proliferator activated receptor (PPAR) agonist, regulates glucose metabolism in rat primary hepatocytes. The FASEB Journal, v.16, p.718-720, 2002.

HELLGREN, L.I. Phytanic acid-an overlooked bioactive fatty acid in dairy fat? Annals of the New York Academy of Science. Issue: Foods for Health in the 21st Century, v.1190, p.42-49, 2010.

HERRMANN, J.; RUBIN, D.; HÄSLER, R. et al. Isomer-specific effects of CLA on gene expression in human adipose tissue depending on PPARgamma2 P12A polymorphism: a double blind, randomized, controlled cross-over study. Journal Lipids in Health and Disease, v.18, p.8-35, 2009.

HOPPE, C.; ANDERSEN, G.S.; JACOBSEN, S. et al. The use of whey or skimmed milk powder in fortified blended foods for vulnerable groups. The Journal of Nutrition, v.138, p.145S161S, 2008.

HOPPE, C.; MøLGAARD C.; MICHAELSEN, K.F. Cow's milk and linear growth in industrialized and developing countries. Annual Review of Nutrition, v.26, p.1-43, 2006.

HUTH, P.J.; DIRIENZO, D.B. MILLER, G.D. Major scientific advances with dairy foods in nutrition and health. Journal of Dairy Science, v.89, p.1207-1221, 2006.

IP, C.; BANNI, S.; ANGIONI, E.G. et al. Conjugated linoleic acidenriched butter fat alters mammary gland morphogenesis and reduces cancer risk in rats. The Journal of Nutrition, v.129, p.2135-2142, 1999.

JENSEN, R.G. Invited review: the composition of bovine milk lipids: January 1995 to December 2000. Journal of Dairy Science v. 85, p.295-350, 2002.

KELLEY, N.S.; HUBBARD, N.E.; ERICKSON, K.L. Critical review: conjugated linoleic acid isomers and cancer. The Journal of Nutrition, v.137, p.2599-2607, 2007.

KEYS, A.; ANDERSON, J.T.; GRANDE, F. Prediction of serumcholesterol response of man to changes in fats in the diet. The Lancet, v.270, p.959-966, 1957.

KRIS-ETHERTON, P.M.; GRIEGER, J.A.; HILPERT, K.F. et al. Review: Milk products, dietary patterns and blood pressure management. Journal of the American College of Nutrition, v.28, p.103S-119S, 2009.

KRISSANSEN, G.W. Review: Emerging health properties of whey proteins and their clinical implications. Journal of the American College of Nutrition, v.26, p.713S-723S, 2007.

LAMARCHE, B. Review of the effect of dairy products on nonlipid risk factors for cardiovascular disease. Journal of the American College of Nutrition, v.27, p.741S-746S, 2008.

LEMAY, D.G.; RIJNKELS, M.; GERMAN, J.B. Commentary: Lessons from the bovine genome: implications for human nutrition and research. The Journal Nutrition, v.139, p.1271-1272, 2009.

LOCK, A.L.; DESTAILlATS, F. Review. A reappraisal of the impact of dairy foods and milk fat on cardiovascular disease risk. European Journal of Nutrition, v.48, p.191-203, 2009.

LOCK, A.L.; DESTAILLATS, F.; KRAFT, J. Introduction to the proceedings of the symposium "Scientific Update on Dairy Fats and Cardiovascular Diseases". Journal of the American College Nutrition, v.27, p.720S-722S, 2008.

MENSINK, R.P.; ZOCK, P.L.; KESTER A.D.M. et al. Effects of dietary fatty acids and carbohydrates on the ratio of serum total to HDL cholesterol and on serum lipids and apolipoproteins: a meta-analysis of 60 controlled trials. American Journal of Clinical Nutrition, v.77, p.114655, 2003

MICKE, P.; BEEH, K.M.; BUHL, R. Effects of long-term supplementation with whey proteins on plasma glutathione levels of HIV-infected patients. European Journal of Nutrition, v.41, p.12-18, 2002.

NESS, A.R.; SMITH, G.D.; HART, C. Milk, coronary heart disease and mortality. Journal of Epidemiology and Community Health, v.55, p.379-382, 2001.

O'FLAHERTY, S.; KLAENHAMMER, T.R. Review: The role and potential of probiotic bacteria in the gut, and the communication between gut microflora and gut/host. International Dairy Journal, v.20, p.262-268, 2010.

OLEFSKY, J.M. Fat talks, liver and muscle listen. Cell Press Journal, v.134, n.9, 2008.

PALMQUIST, D.L. Milk fat: origin of fatty acids and influence of nutritional factors thereon. In: FOX, P.F.; MCSWEENEY, P.L.H. (Eds.) 3.ed. Advanced dairy chemistry. Springer Science: New York, 2006a. p.43-92.

PALMQUIST, D.L.; GRIINARI, JM. Milk fatty acid composition in response to reciprocal combinations of sunflower and fish oils in the diet. Animal Feed Science and Technology, v.131, p.358-369, 2006b.

PALMQUIST, D.L. n-3 Fatty acids in metabolism, health, nutrition and for modified animal product foods. The Professional Animal Scientist, v. 25, p.207-249, 2009.

PALMQUIST, D.L.; LOCK, A.L.; SHINGFIELD, K.J. et al. Biosynthesis of conjugated linoleic acid in ruminants and humans. Advances in Food and Nutrition Research, v.50, p.179-217, 2005.

PARODI, P.W. Conjugated linoleic acid in food. Advances in Conjugated Linoleic Acid Research, v.2, p.101-122, 2006.

PARODI, P.W. A role for milk proteins and their peptides in cancer prevention. Current Pharmaceutical Design, v.13, p.813828, 2007.

PARODI, P.W. Review: has the association between saturated fatty acids, serum cholesterol and coronary heart disease been over emphasized? International Dairy Journal, v.19, p.345-361, 2009.

PAUL, G.L. Review. The rationale for consuming protein blends in sports nutrition. Journal of the American College of Nutrition, v.28, p.464S-472S, 2009.

PEREIRA, M.A.; JACOBS, D.R.; Van HORN, L. Dairy consumption, obesity, and the insulin resistance syndrome in young adults. The CARDIA study. The Journal of the American Medical Association, v.287, p.2081-2089, 2002.

PFEUFFER, M.; SCHREZENMEIR, J. Milk and the metabolic syndrome. Obesity Reviews, v.8, p.109-118, 2006.

PHELAN, M.; AHERNE, A.; FITZGERALD, R.J. et al. Review: Casein-derived bioactive peptides: Biological effects, industrial uses, safety aspects and regulatory status. International Dairy Journal, v.19, p.643-654, 2009.

RAMAKERS, J.D.; PLAT, J.; SÉBÉDIO, J.L. et al. Effects of the individual isomers cis-9, trans-11 vs. trans-10,cis-12 of conjugated linoleic acid (CLA) on inflammation parameters in moderately overweight subjects with LDL-phenotype B. Lipids, v.40, p.909-918, 2005.

REID, G. Review: Probiotics and prebiotics - Progress and challenges. International Dairy Journal, v.18, p.969-975, 2008.

RIJKERS, G.T.; BENGMARK, S.; ENCK, P. et al. Guidance for substantiating the evidence for beneficial effects of probiotics: Current status and recommendations for future research. The Journal of Nutrition, v.140, p.671S-676S, 2010.

SHINGFIELD, K.J.; AHVENJAHRVI, S.; TOIVONEN, V. et al. Effect of dietary fish oil on biohydrogenation of fatty acids and milk fatty acid content in dairy cows. Journal of Animal Science, v.77, p.165-179, 2003.

SILVA, S.V.; MALCATA, F.X. Review: caseins as source of bioactive peptides. International Dairy Journal, v.15, p.1-15, 2005.

SIRI-TORINO, P.W.; SUN, Q.; HU, F.B et al. Saturated fat, carbohydrate, and cardiovascular disease. American Journal of Clinical Nutrition, v.91, p.535-546, 2010. 
SJÕGREN, P.; ROSELL, M.; SKOGLUND-ANDERSSON, C. et al. Milk derived fatty acids are associated with a more favorable LDL particle size distribution in healthy men. The Journal of Nutrition, v.134, p.1729-1735, 2004.

SMITHERS, G.W. Review: Whey and whey proteins-From 'gutterto-gold’. International Dairy Journal, v.18, p.695-704, 2008.

TURPEINEN, A.M.; MUTANEN, M.; ARO, A. et al. Bioconversion of vaccenic acid to conjugated linoleic acid in humans. American Journal of Clinical Nutrition, v.76, p.504-510, 2002.

Van WIJlEN, R.P.J.; COLOMBANI, P.C. Review: grass-based ruminant production methods and human bioconversion of vaccenic acid with estimations of maximal dietary intake of conjugated linoleic acids. International Dairy Journal, v.20, p.433-448, 2010

VASILJEVIC, T.; SHAH, N.P. Review: probiotics-From Metchnikoff to bioactives. International Dairy Journal, v.18, p.714-728, 2008.

WARD, R.M.; GERMAN, J.B. Understanding milk's bioactive components: A goal for the genomics toolbox. The Journal of Nutrition, v.134, p.962S-967S, 2004.

WARENSJÕ, E.; JANSSON, J.-H.; BERGLUND, L. et al. Estimated intake of milk fat is negatively associated with cardiovascular risk factors and does not increase the risk of a first acute myocardial infarction. A prospective case-control study. British Journal of Nutrition, v.91, p.635-642, 2004.

WARENSJÖ, E.; SMEDMAN, A.; STEGMAYR, B. et al. Stroke and plasma markers of milk fat intake - a prospective nested case-control study. Nutrition Journal, v.8, p.21, 2009. Published online 2009 May 21. doi: 10.1186/1475-2891-821.

WHIGHAM, L.D.; WATRAS A.C.; SCHOELLER. D.A. Efficacy of conjugated linoleic acid for reducing fat mass: a meta-analysis in humans. American Journal of Clinical Nutrition, v.85, p.1203-1211, 2007.

WILLETT, W.C.; STAMPFER, M.J.; MANSON, J.E. et al. Intake of trans fatty acids and risk of coronary heart disease among women. The Lancet, v.341, p.581-585, 1993.

ZEMEL, M.B. Role of calcium and dairy products in energy partitioning and weight management. American Journal of Clinical Nutrition, v.79(suppl), p.907S-912S, 2004a.

ZEMEL, M.B. Review: The role of dairy foods in weight management. Journal of the American College of Nutrition, v.24, p.537S-546S, 2005.

ZEMEL, M.B.; THOMPSON, W.; MILSTEAD, A. et al. Calcium and dairy acceleration of weight and fat loss during energy restriction in obese adults. Obesity Research, v.12, p.582590, 2004b. 